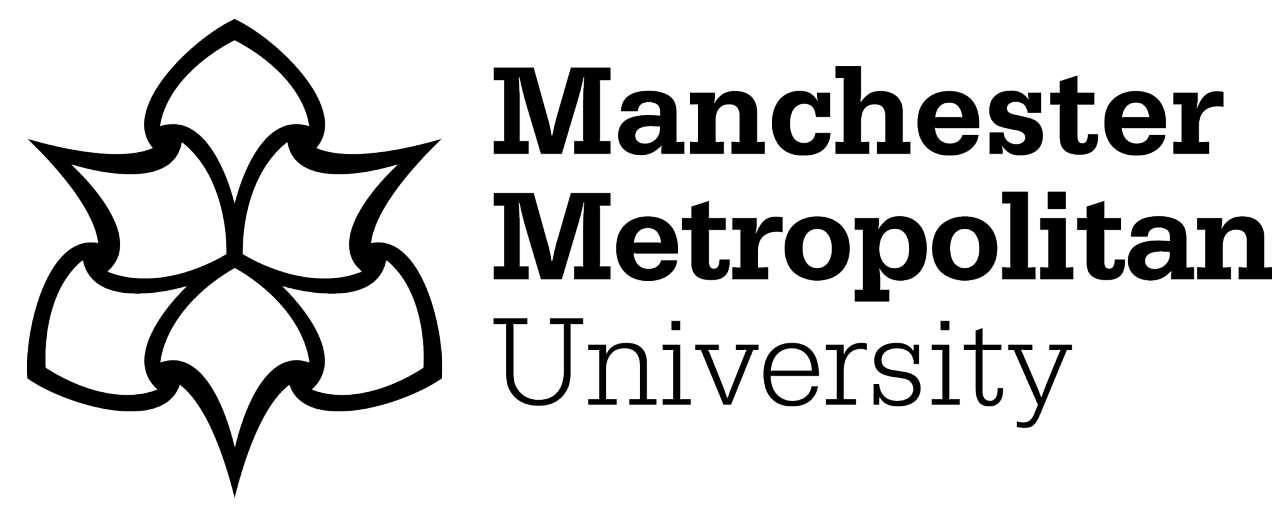

Saridakis, George, Lai, Yanqing ORCID logoORCID: https://orcid.org/00000001-9107-3464, Mohammed, Anne-Marie and Hansen, Jared M (2017) Industry characteristics, stages of E-commerce communications, and entrepreneurs and SMEs revenue growth. Technological Forecasting and Social Change, 128. pp. 56-66. ISSN 0040-1625

Downloaded from: https: //e-space.mmu.ac.uk/623802/

Version: Accepted Version

Publisher: Elsevier BV

DOI: https://doi.org/10.1016/j.techfore.2017.10.017

Usage rights: Creative Commons: Attribution-Noncommercial-No Derivative Works 3.0

Please cite the published version 


\title{
Industry characteristics, stages of E-commerce communications, and entrepreneurs and SMEs revenue growth
}

\author{
George Saridakis $^{\mathrm{a}, *}$, Yanqing Lai ${ }^{\mathrm{b}}$, Anne-Marie Mohammed ${ }^{\mathrm{c}}$, Jared M. Hansen ${ }^{\mathrm{d}}$ \\ ${ }^{\text {a }}$ Kingston University, Small Business Research Centre, Faculty of Business and Law, United Kingdom \\ b Edinburgh Napier University, Business School, United Kingdom \\ ${ }^{c}$ The University of the West Indies, Faculty of Social Sciences, Department of Economics, Trinidad, Trinidad and Tobago \\ ${ }^{\mathrm{d}}$ University of North Carolina at Charlotte, Belk College of Business, United States
}

\section{A R T I C L E I N F O}

\section{Keywords:}

Entrepreneurial strategy

Small and medium-sized enterprises (SMEs)

E-commerce development stages

Social media revenue

Third-party websites

Industry

\begin{abstract}
A B S T R A C T
This paper empirically examines the role of industry characteristics portrayed by information intensity of value chain or product in the relationship between the stages of E-commerce development and revenue growth for a large representative sample of small and medium-sized enterprises (SMEs) and other entrepreneurs who operate in the United Kingdom. The results indicate that SMEs characterised by (A) high information intensity of value chain or product of industry that (B) have their own business website, a third-party website and/or a social profile, on average more often report increases in revenue growth versus their counterparts in either (A) other industries or that (B) do not have the E-commerce development. However, the likelihood of improved performance does not vary significantly among SMEs which are at different development stages of E-commerce. This finding holds regardless of whether the business is in a high value chain information intensive industry or a product information intensive industry. In short, business performance appears to improve as entrepreneurial organizations adopt information technology to facilitate greater market communication and increased exposure to online shoppers. Furthermore, this is irrespective of the level of sophistication of the interface, the design of the E-commerce technology and the high information intensity types of the industry. To conclude, this paper presents some discussions and recommendations for entrepreneurial research and practice that are implied by the results.
\end{abstract}

\section{Introduction}

As part of the strategic choices in 'business model' formulation and evolution, entrepreneurs must choose how their small and mediumsized enterprises (SMEs) will interact with customers and deliver value to them (Morris et al., 2006). Part of that strategic decision involves deciding on which, if any, of the stages of E-commerce development, they should spend their time and resources to create for the SME (Daniel and Wilson, 2002; Rao et al., 2003). This choice is possible because the World Wide Web has effectively flattened the playing fields by lowering the barriers to firm entry, resulting in many new entrants to the markets, and in particular the entrepreneurs' SMEs (Dahnil et al., 2014; Kim, 2003; Öztamur and İbrahim, 2014; Shin, 2001; Sinkovics and Penz, 2006; Wen et al., 2001).

This preceding development is important because (1) entrepreneurs' SMEs are a critical component of many economies-e.g., in the UK economy SME's employ over $70 \%$ of the total workforce-and (2) E- commerce represents a most viable way of developing efficient retail channels and thus, overcoming their inherent resource constraints (Kirchhoff, 1994; Kirchhoff et al., 2013; Storey, 1994). E-commerce is an internet-based commercial transaction that benefits from the flexibility and speed offered by electronic communications between buyers and sellers, which can lead to substantial costs savings, increased competitiveness and efficiency for SMEs through the redesign of traditional business methods (Chen and Zhang, 2015). Aside from lowering their investment and transaction costs of developing both marketing and distribution channels, E-commerce also minimizes transport obstacles and eliminates the physical limitations of time and space, therefore, enabling SMEs to enlarge their customer bases (Santarelli and D'Altri, 2003). Specifically, internet-based E-commerce enables SMEs to communicate better and interact with potential new and existing customers, to conduct less costly market research, and to deliver various customer services and support more effectively and efficiently (Auger and Gallaugher, 1997; Hoffman and Novak, 1995).

\footnotetext{
* Corresponding author.

E-mail addresses: G.Saridakis@kingston.ac.uk (G. Saridakis), Y.Lai@napier.ac.uk (Y. Lai), Anne-Marie.Mohammed@sta.uwi.edu (A.-M. Mohammed), jared.hansen@uncc.edu (J.M. Hansen).
} 
Research has shown that over half of SMEs in some way or the other actively participate in the marketing and selling of products and/or services in the online marketplaces and communities (Morris et al., 2006). Furthermore, they use the online marketplaces and communities for the dissemination of their products, services contact information, the provision of customer reviews, online orderings and payments, and social media based brand communications (Huang and Benyoucef, 2013; Kietzmann et al., 2011; Laroche et al., 2012). However, this statistic also means that nearly half of SMEs have not adopted any stage of E-commerce development.

One plausible explanation of this happening lies within the domain of guided mastery modelling, which proposes that both employees and their supervisors have to achieve E-commerce competence. Further, this theory suggests that the supervisors need to guide employees. Thus, the adoption of E-commerce as a new skill will take time depending on the human capital of the SMEs (Wood and Bandur, 1989); even though the SMEs are within the same industry, they all have different capabilities (Galbraith, 1995). Therefore, the time taken for each to adopt E-commerce will be different. E-commerce is a new marketing paradigm; as such there are inherent uncertainties associated with it. Therefore, according to the information processing model, the SMEs will take a certain amount of time to adopt this paradigm to affect performances positively (Galbraith, 1976). Another plausible explanation may be associated with the contextual relevance of the factors of the firm. For instance, the heterogeneous nature of industries in which small firms operate. Thus, it is logical to argue that the impacts of using E-commerce to alter customer-supplier-interfaces and streamline international procedures can differ significantly from industry to industry (Preissl, 2003). The importance of industry characteristics in the linkage between E-commerce and performance is widely acknowledged (Melville et al., 2004). Yet still, there is a paucity of studies on the mechanisms of the roles employed to represent industry characteristics in the context of the small business population. In this article, we apply the concept of information intensity of value chain information and product matrix, as proposed by Porter and Millar (Porter and Millar, 1985), to complement the transaction cost theory (Williamson, 1991) and the product fit theory to advance the understanding of the performance discrepancy between E-commerce adopters and non-adopters in the SMEs.

In addition, prior research finds that many SMEs who adopted Ecommerce, did not do so strategically (Quayle, 2002). It is unknown whether the adoption of the different stages of E-commerce development has resulted in improvements in revenues or if it has just added extra costs and complexities to the SMEs of the entrepreneurs. For instance, the design and maintenance of a commercial website requires a large volume of financial capital. Therefore, it is important for SMEs to know whether adopting the different stages of E-commerce positively affects revenue. In other words, the extent to which the E-commerce contributes to organizational performance is partially dependent on the interface sophistication, as well as the functionality and design of the web-based transaction platforms.

Hence, the contribution of the present study is twofold: firstly, it examines whether the relationship between the adoption of internetbased E-commerce technologies and revenue growth in SMEs varies among industries in terms of the information intensity of value chain or product; and secondly, it determines whether there is a difference in the percentages of groups succeeding by looking across and comparing the three different development stages of E-commerce: presence, portals and transaction integration [see (Rao et al., 2003)]—examining the usage of firm websites, third-party websites, and social media for Ecommerce. The hypotheses are examined through analysis of a representative sample of SMEs in the United Kingdom.

The rest of the paper proceeds as follows. Firstly, the authors outline hypotheses drawing upon the existing literature and logic in the Theory and hypotheses section. Then in the Data section and Methods section the authors describe the research sample, the measures, and the analysis techniques. Results are then presented, implications outlined, and finally the conclusions drawn.

\section{Theory and hypotheses}

\subsection{E-commerce technologies}

E-commerce is broadly defined as a transaction in which the internet is used first as a platform to establish the terms of trade (e.g. price, availability, order processing time to delivery) among the participants in a marketing channel, and second, to sell goods and services that can be delivered offline (i.e., the services can be 'digitised') and delivered online (Shin, 2001). Products and services offered in the digital economy can be delivered through information-based channels, thus, reaching an enlarged customer base. Furthermore, the information itself is considered as a source of value and presents opportunities to develop new relationships with customers at very low costs. In the present study, we focus on (A) three different choices of internet technologies to reach customers-i.e., the SME's own website, thirdparty websites, and the SME's social media presence; (B) different stages of usage-as each technology could (1) not be used, or it could be used at the (2) presence stage (to show information), (3) portal stage, or (4) transaction integration stage (Rao et al., 2003).

A SME's own website that can be used for presence, portal, or transaction is one of the main vehicles for content marketing (Wainwright, 2014). Namely, content marketing involves unrequited sharing of beneficial product information, ideas, and experiences to the users or communities ${ }^{1}$ of consumers by the firm (Ahmad et al., 2006; Blank, 2014). Therefore, it is ... "a strategic marketing approach that focused on creating and distributing valuable, relevant, and consistent content to attract and retain a clearly-defined audience to gain profit" (Content Marketing Institute, 2015). In other words, it is geared towards creating and strengthening within the consumer's mind, the firm's brand image, which translates into firm growth via sales and increased shareholder values (Ahmad et al., 2006; Cornelissen, 2014; Keller, 2009; Pachitanu, 2016; Young, 2014). Today, the brand is a very significant determinant of firm growth and performance, with regards to profits (Zhu and Kraemer, 2002), sales, and consumer loyalty (Berger et al., 2007). To be more precise, a healthy brand ensures a forward looking competitive position, thus, it is really about the image of the brand, as this reflects the image and identity of the firm itself (Ahmad et al., 2006). In short, not all websites are created to focus on transactions. Often entrepreneurial SMEs first establish a website simply to show and/or gather information (i.e. presence stage).

Likewise, third-party website usage includes the strategic choice to focus usage on establishing presence, portal, or transactions. For instance, when the firms have information about their products that they are not desirous of sharing to consumers, giving rise to information asymmetry. This has significantly contributed to the emergence of the new phenomenon of the market, which is commonly referred to as third-party product reviews (Akerlof, 1970; Nelson, 1974). Nevertheless, this phenomenon, which is one of the most effective yet least understood of marketing strategies (Misner, 1999) became increasingly popular after Amazon.com brought out the first customer review book in 1995 . Thus, by 2008 , some $43 \%$ of the online retailers started to do so on their own websites (Gogoi, 2007). Precisely, there was a free flow of information from customers to potential customers on an extensive product array: the emergence of the word-of-mouth as a marketing phenomenon (de Valck et al., 2009). In fact, market researchers have found that customers place greater trust in online reviews when

\footnotetext{
${ }^{1}$ The concept of communities was first termed by Rheingold (Rheingold, 1993) as virtual communities: "social aggregations that emerge from the Net when enough people carry on those public discussions long enough, with sufficient human feeling, to form webs of personal relationships in cyberspace" and can be also termed: virtual worlds, virtual realities, virtual presence and online communities (Lange-Faria and Elliot, 2012).
} 
compared to other forms of marketing communication (Campanell, 2006) such that even offline purchases are heavily influenced by online reviews (Chevalier and Mayzlin, 2004; Jiang and Wang, 2008; Senecal and Nantel, 2014; Thompson, 2003). Clearly, third-party websites can impact significantly on firm growth, as they are based upon word-ofmouth: "Whereas marketing plays an important role in a movie's opening weekend, consumer word-of-mouth has been frequently cited as the single most important factor that determines the long-term success of motion pictures and other experience goods" (De Vany and Walls, 1996; Dellarocas et al., 2007).

\subsection{Linking E-commerce to firm performance: transactional cost economics perspective}

There is a growing number of SMEs which utilize E-commerce at different levels of their businesses. Particularly, E-commerce technologies have been widely used to improve the operational aspects such as order processing, fulfilment and delivery, as well as the marketing aspects such as online advertising (Ramanathan et al., 2012). It is argued that E-commerce provides cost-effective ways of using resources available to a firm to enter into new markets, increase customer base, streamline supply chains, improve customer service, reduce costs and increase profits (Johnstone et al., 2007; Karavdic and Greogory, 2005; Santarelli and D'Altri, 2003). Various theoretical lenses have been used to understand how E-commerce impacts firm performance. For example, Sila [(Sila, 2013), p. 203] summarized the usage of 25 different theories by several dozen studies on E-commerce technology adoption, including transaction costs economics (TCE) theory.

The TCE posits that boundary decisions are based on comparison of the performance of alternative governance institutions (Williamson, 1991). In organizational settings, a firm seeks to achieve performance maximization by matching exchanges that vary in attributes to governance structures, which is then subsequently employed in the determination of comparative performance, particularly the transaction costs and production cost efficiencies of alternative forms (Ke and Wei, 2007). To achieve the optimal level of performance, organizations opt to a governance structure that facilitates the minimization of transaction and/or production costs (Williamson, 1991). It is believed that the introduction of E-commerce reduces transaction costs, which in turn leads to improved firm performances. Specifically, internet-based transactions potentially affect two types of transaction costs: coordination and motivation costs. Coordination costs incur from '...the need to determine prices and other details of the transaction, to make the existence and location of potential buyers and sellers known to one another, and to bring the buyers and sellers together to transaction' [(Milgrom and Roberts, n.d.), p. 28]. Motivation or incentive costs arise from those in relation to informational asymmetries and imperfect commitment (Garicano and Kaplan, 2001).

Internet technology in any of the three choices potentially influences both coordination and motivation costs. Firstly, it may reduce coordination costs associated with an existing business process, either by significantly reducing the costs of an activity already being undertaken, or by providing an opportunity to redesign the existing ones (Garicano and Kaplan, 2001). For instance, while it may not significantly reduce market entry and distributive costs, it may reach a significant number of customers without incurring the higher costs of organizing a proprietary marketing channel (Santarelli and D'Altri, 2003). Secondly, it generates mutual benefits for both buyers and sellers by reducing the cost of matching buyers and sellers. For example, it offers a less time-consuming and expensive means for buyers to search for goods and to compare their prices, and for sellers to identify potential buyers.

The adoption of the E-commerce may be perceived as a doubleedged sword because the internet has the potential to exert an impact on motivation or incentive costs in relation to informational asymmetries and imperfect commitment. Firstly, informational asymmetries are likely to deteriorate because buyers cannot physically observe the merchandise and evaluate the conditions of the goods and/or services. Secondly, the internet may change the costs of commitment. Nevertheless, this cost can be significantly lowered as a result of the standardization of the process and the presence of an electronic trail. In addition, intermediary fees can be eliminated since buyers can view the goods over the internet and make direct contact with merchandisers. In a word, internet technologies can reduce transaction cost frictions and improve operational efficiency and thus performance by providing costeffective ways of using resources available to a firm. This is particularly important for SMEs given that they are often characterised with resource poverty or constraint (Storey, 1994).

\subsection{The role of industry characteristics: information intensity of value chain and product}

Researchers, on the other hand, have suggested that the relationship between the use of the E-commerce and firm performance may vary significantly between organizations because of a wide range of firm and environmental characteristics [for a comprehensive review, see (Dewett and Gareth, 2001)]. One of the factors that can potentially lead to performance discrepancy in utilizing E-commerce is the nature of industry. Portrayed by information intensity of value chain and product (Porter and Millar, 1985), we thus argue that the effectiveness of Ecommerce adoption in SMEs is conditional upon industry characteristics. Many of the discussed theoretical models have positioned the analysis within the level of individual organizations. However, it is reasonable to assume that the collective behaviour of all firms in an industry can reflect the behaviour of the majority, given that each industry has its own value chain activities and strategies (Hu and Quan, 2003). The transaction economics cost perspective focuses on the impact of the internet on the efficiency of transaction costs. Thereby, it provides the underlying theoretical logic that the size of information intensity of the value chain of the industry influences the effects of Ecommerce on firm performance. According to TCE, E-commerce can generate higher levels of firm performance because it lowers the costs, speeds up activities in the value chain, reduces overall transaction costs and improves operational efficiency (Rotondaro, 2002). Arguably, it is operationally more effective and profitable for an organization to employ E-commerce technologies, if the transaction costs of the process are reduced by internet usages (Lightfoot and Harris, 2003). In other words, industries with high value chain information intensity (e.g. retailing and wholesaling, manufacturing, transportation) are more likely to achieve the optimal level of benefits when compared to those with low value chain information intensities (e.g. small business in the service sector). This is so, because the efficiency of the entire value chain of the former industries are heavily influenced by the efficiency of the information processing caused by the extreme complexity of logistics and internal material flow and control (Hu and Quan, 2003). For example, the applications of E-commerce technologies can significantly improve the operational efficiency of the value chain by reducing slacks, cycle and time etc.

Alternatively, the product fitness theory postulates that products and services encompass a high intensity of product information and are more suitable for online advertising and transactions if they can be easily digitised, or if more information is needed by customers to use them (Schwartz, 1997). Specifically, if the primary product or service moving through the primary value chain activities is information (e.g. information and communication; professional and banking industry), then extensive utilization of E-commerce can boost operational efficiency. In contrast, the benefit of improvement in operational efficacy in the adoption of such technologies may not be as comparable as, or even impossible for, the industries that offer physical goods (e.g. transportation and storage, construction, accommodation and food industry). Hence, we hypothesised that:

H1a: SMEs in the value chain information intensive industry that use E- 
commerce technologies are more likely to have a positive revenue increase versus those in that industry that do not use E-commerce technologies.

$H 1 b$ : SMEs in the product information intensive industry that use Ecommerce technologies are more likely to have a positive revenue increase versus those in that industry that do not use E-commerce technologies.

\subsection{Stages of E-commerce development}

Assuming a theorized positive relationship exists between E-commerce and performance growth as stated in H1, we next turn our attention to the question of whether the positive association is significantly different for each stage of development. As indicated prior, Rao et al. (Rao et al., 2003) proposed a four-stage model for E-commerce development in SMEs: 1) presence; 2) portals; 3) transactions integration; and 4) enterprise integration. Though the stage model appears sequential, it is possible for a company to start at any stage and progress towards the later stage. However, existing research finds that a large majority of firms begin with the presence stage by displaying their company brochures and product offers on a website (Timmers, 2001). Thus, in a static way, information is provided about the company's products and services, contacts, and other relevant information; primarily in a one-way communication to any potential user or client. O'Connor and O'Keefe (O'Connor and O'Keefe, 1997) suggest that the presence is used to attract new customers and therefore the integration with internal and/or external processes is minimal.

At the portals stage, businesses introduce two-way communications. Two-way communication between the business and customer (B2C) and/or between businesses (B2B) is the major attribute of this stage that differs significantly from the presence stage. In addition to the information available at presence stage, the portals offer facilities for ordering, product feedback, and product and/or quality surveys. The additional features not only allows businesses to engage, retain, and relate visitors to their individual preferences, thereby, serving customization purposes (Le and Koh, 2002); it also enables businesses to link the information that is displayed with inventory data and search capabilities that benefit the users (Timmers, 1999). The transaction integration stage entails the financial transactions between sellers and buyers. This stage involves participation in the virtual communities that allow for information-sharing among participants around an area of common interest in virtual communities (Timmers, 2001). Specifically, firms offer products or services to buyers through a website with a structured procedure for price setting, order fulfilment, and third-party e-marketplaces, whereas a third-party provider promotes the goods and services of the firm and offers ordering and payment facilities in a secure environment to buyers (Rao et al., 2003). Rao et al.'s (Rao et al., 2003) development model of internet-based E-commerce not only describes how a firm utilizes E-commerce to operate the business but also the logical evolution of E-commerce at different stages of development by providing a roadmap for improvement. In addition to this, it is expected that business performance improves as development stage advances. $^{2}$ We hypothesize that:

H2a: The likelihood of increased revenue is stronger for SMEs in the value chain information intensive industry that use the portal stage of $E$ commerce than for those in that industry that use the presence stage of $E$ commerce.

H2b: The likelihood of increased revenue is stronger for SMEs in the product information intensive industry that use the portal stage of E-commerce than for those in that industry that use the presence stage of E-commerce.

H3a: The likelihood of increased revenue is stronger for SMEs in the

\footnotetext{
${ }^{2}$ Since the data allows us to investigate three out of four stages of E-commerce development (i.e. the survey does not provide information on enterprise integration), we focus on the effect of presence, portals and transactions integration development stage on SME firm performance.
}

value chain information intensive industry that use the transaction stage of E-commerce than for those in that industry that use the presence stage of $E$ commerce.

H3b: The likelihood of increased revenue is stronger for SMEs in the product information intensive industry that use the transaction stage of $E$ commerce than for those in that industry that use the presence stage of $E$ commerce.

H4a: The likelihood of increased revenue is stronger for SMEs in the value chain information intensive industry that use the transaction stage of $e$ commerce than for those in that industry that use the portal stage of $E$ commerce.

H4b: The likelihood of increased revenue is stronger for SMEs in the product information intensive industry that use the transaction stage of $E$ commerce than for those from that industry that use the portal stage of $E$ commerce.

\section{Data}

\subsection{Sample}

For this study, the authors acquired data from the Small Business Survey (SBS) 2015, which is a nationally representative UK employer database. The database contains answers from a stratified sample of 15,502 UK small business owners and managers for SMEs that employ between 1 and 249 employees as well as businesses without any employees. More information about the telephone-based survey, the construction of the sampling procedure, and summary statistics of collected data is available online at the Department for Business, Innovation \& Skills (BIS) Webpage at https://www.gov.uk/ government/collections/small-business-survey-reports.

\subsection{Dependent variable}

Firm performance is measured by actual growth in sales revenue (referred to as 'turnover' in the UK) for the previous 12 months. The survey question states: 'Compared with the previous 12 months, has your turnover in the past 12 months increased, decreased or stayed roughly the same?' The authors coded data on a binary scale, and coded as 1 if 'increased' (28.85\%), or 0 if 'stayed roughly the same' or 'decreased' (71.15\%).

\subsection{Independent variables}

The independent variables regarding utilization of technology are measured using relevant questions in the Small Business Survey dataset. In particular, the use of internet technology is examined from three aspects: firstly, whether the business has its own website; secondly, whether the business uses a third-party website to promote or sell goods or services, e.g. Amazon, Etsy, or eBay; and thirdly, whether the business has its own social media profile, such as on Facebook, LinkedIn or Twitter. The responses are evaluated on a binary scale, coded as 1 if 'yes', and 0 if 'no'.

There are several follow-up questions that are posed to the respondent managers/owners depending on whether they answer 'yes' to above question(s), which allows us to examine the extent to which various development stages of E-commerce influence performance growth in SMEs. For businesses that have their own company website and or a third-party website, they are asked to clarify the ways in which the website has been used, including: 'So that customers can order and pay for goods or services directly from your/the other website?'; 'to take booking or orders, without payment at the time?'; or 'to promote or showcase your goods or services, with contact details so that customers can get in touch?' The first specification refers to the 'transaction integration' stage of E-commerce, whereas the latter two refer to the 'portal' stage of Ecommerce [for more details see (Rao et al., 2003)]. Regarding those small firms which have a social media profile, only one follow-up 
question is asked; 'Are you using social media so customers can order to buy goods or services from you?' This implies that for the development stage of using a social media profile, only the effect of presence stage and transaction stage on performance growth can be compared (i.e. H3). Therefore, we use this information to categorize firms into groups according to the E-commerce development stage: presence, portals, and transaction integration stage of E-commerce.

\subsection{Industry characteristics}

The SBS categorizes the participating SMEs into 14 different industries which are based on the 2007 UK Standard Industrial Classification (SIC) including: (1) Primary, (2) Manufacturing, (3) Construction, (4) Wholesale/Retail, (5) Transport/Storage, (6) Accommodation/Food, (7) Information/Communication, (8) Financial/ Real Estate, (9) Professional/Scientific, (10) Administrative/Support, (11) Education, (12) Health/Social Work, (13) Arts/Entertainment, and (14) other services. Using the product-information intensity matrix, these industries ${ }^{3}$ are further grouped into three categorizations: a) value chain information intensive industry; b) product information intensive industry; and c) neither value chain information intensive industry nor product information intensive industry (see Fig. 1). Table 1 presents the weighted proportion of different stages of E-commerce technologies adoption based on industry characteristics in relation to the intensity of value chain information and product information. SMEs in the product information intensive industry have the highest level of the use of all E-commerce technologies, followed by those in the value chain information intensive industry and primary industry in sequence.

\subsection{Firm characteristics}

As stated by Clarysse et al. [(Clarysse et al., 2011), p. 137], "environmental contingencies determine the way resources are accumulated in young technology-based firms." Consistent with that idea, we identified several other potential control variables from elements that were examined in prior research on SMEs that might influence performance. In particular, within the dataset we are able to control for the following firm characteristics: the capability of people management, the capability for accessing external finance, family ownership structure, firm size, age, industry, legal status, geographical locations, presence of working owners/partners and the number of sites in operation (Barth et al., 2005; Olson et al., 2003; Sciascia et al., 2012). More specifically, two forms of business capabilities are included: (1) the extent to which the business is capable of developing people management skills and (2) the access of external finances. Family ownership is measured by the item which determines whether the majority of the business is owned by the members of the same family. Firm size is constructed by the log of the number of employees currently on the payroll. Firm age is constructed by the number of years the firm had been trading. Legal status is categorized into four types: sole proprietorship, company, partnership and other. Geographical location is the nation where the business located (i.e. England, Scotland, Wales and Northern Ireland). The working owners/partners work in the business is measured by whether they are presented or not (yes or no). The Number of sites is constructed by the log of the number of sites in operation including the head office in the UK.

\section{Methods}

In order to investigate empirically the relationship between the use of technology and firm performance (i.e. revenue growth) in UK SMEs (H1), we perform probit regression estimations controlling for several

\footnotetext{
${ }^{3}$ We excluded (14) other services in the analysis because specific nature of industries included in this category was not given.
}

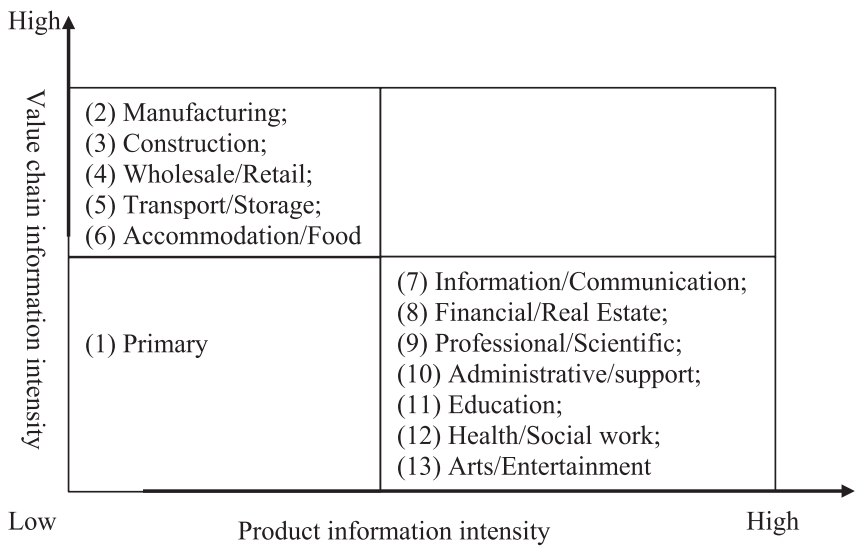

Fig. 1. Industry categorizations: Information-Product intensity matrix.

Table 1

Stages of E-commerce technologies adoption in SMEs in different industries (weighted proportion).

\begin{tabular}{|c|c|c|c|}
\hline \multirow{2}{*}{$\begin{array}{l}\text { E-commerce } \\
\text { technologies: the SME } \\
\text { has }\end{array}$} & \multicolumn{3}{|c|}{ Industry characteristics } \\
\hline & $\begin{array}{l}\text { Primary } \\
\text { industry }\end{array}$ & $\begin{array}{l}\text { Value chain } \\
\text { information } \\
\text { intensive }\end{array}$ & $\begin{array}{l}\text { Product } \\
\text { information } \\
\text { intensive }\end{array}$ \\
\hline \multicolumn{4}{|l|}{ Its own website? } \\
\hline No & $66 \%$ & $44 \%$ & $28 \%$ \\
\hline $\begin{array}{l}\text { Yes (and which } \\
\text { stage?) }\end{array}$ & $34 \%$ & $56 \%$ & $72 \%$ \\
\hline Presence stage & $2 \%$ & $2 \%$ & $2 \%$ \\
\hline Portal stage & $25 \%$ & $43 \%$ & $58 \%$ \\
\hline $\begin{array}{l}\text { Transaction } \\
\text { integration stage }\end{array}$ & $8 \%$ & $11 \%$ & $13 \%$ \\
\hline \multicolumn{4}{|l|}{ A third party website? } \\
\hline No & $88 \%$ & $82 \%$ & $79 \%$ \\
\hline $\begin{array}{l}\text { Yes (and which } \\
\text { stage?) }\end{array}$ & $12 \%$ & $18 \%$ & $21 \%$ \\
\hline Presence stage & $1 \%$ & $1 \%$ & $1 \%$ \\
\hline Portal stage & $7 \%$ & $10 \%$ & $15 \%$ \\
\hline $\begin{array}{l}\text { Transaction } \\
\text { integration stage }\end{array}$ & $4 \%$ & $7 \%$ & $5 \%$ \\
\hline \multicolumn{4}{|l|}{ A social media profile? } \\
\hline No & $79 \%$ & $62 \%$ & $51 \%$ \\
\hline $\begin{array}{l}\text { Yes (and which } \\
\text { stage?) }\end{array}$ & $21 \%$ & $38 \%$ & $49 \%$ \\
\hline Presence stage & $18 \%$ & $28 \%$ & $38 \%$ \\
\hline $\begin{array}{l}\text { Transaction } \\
\text { integration stage }\end{array}$ & $3 \%$ & $10 \%$ & $11 \%$ \\
\hline
\end{tabular}

Notes: Primary industry is neither value chain information intensive nor product information intensive. Percentages may not add up due to rounding.

firm-specific characteristics. We use a probit model using a maximum likelihood estimation since we have an index model with two alternatives: the variable capturing firm performance takes values from 0 (performance decreased or same) to 1 (performance increased). Briefly, the model is represented as:

Performance $_{f}^{*}=a_{1}$ Internet Technology ${ }_{f}+b^{\prime} X_{f}+u_{f}$

where Performance ${ }_{f}^{*}$ represents the latent dependent variable and although it is unobserved, we observe Performance $_{f}$ such that:

Performance $_{f}=j$ if $\mu_{j-1}<$ Performance $_{f}^{*} \leq \mu_{j}$

where the $a, b$ and $\mu$ are the parameters to be estimated. $X_{f}$ is a row vector of firm characteristics. In other words, the probability that alternative $\mathrm{j}$ is chosen is the probability that the Perfromance ${ }_{f}^{*}$ is between two boundaries $\mu_{j-1}$ and $\mu_{j}$.

In addition to this, to address a potential selection problem in (Caliendo and Kopeing, 2008) a propensity score, matching is a 
statistical technique that is used. Assuming that there are two potential outcomes, $Y_{i}^{1}$ (business $i$ use a particular form of E-commerce, $T=1$ ) and $\mathrm{Y}_{i}^{1}$ (business $\mathrm{i}$ does not use a particular form of E-commerce, $T=0$ ), the ideal average treat effect (ATT) on the treated can thus, be represented as:

$\mathscr{T}_{\text {ATT }}^{\text {ideal }}=E\left(Y^{1} \mid T=1\right)-E\left(Y^{0} \mid T=1\right)$

The second term is the hypothetical one; it is the expected value of the outcome for business without treatment (i.e. using any form of Ecommerce technology) but who participated in the treatment. In the sample, the only observed outcome is $E\left(Y^{0} \mid T=0\right)$; and it is typically not equal to $E\left(Y^{0} \mid T=1\right)$, because of the systematic differences between the outcomes of treated individuals and those of the untreated ones. One possible solution to address this issue is to apply a propensity score matching estimator that will compare the outcomes of treated groups with the outcome of an adequate control group, however, two conditions must be satisfied [(Kampkotter and Marggraf, 2005), p. 2898].

The first requires that conditional upon the propensity score $\left(P\left(X_{i}\right)\right.$, the counterfactual outcome is independent of the treatment: $\mathrm{Y}^{0} \perp \mathrm{T} \mid(P$ $\left(X_{i}\right)$. Meanwhile, the next condition that must hold is the overlap condition, which requires $0<\operatorname{Pr}\left(\mathrm{T}=1 \mid P\left(X_{i}\right)\right)<1$. These two conditions ensure that there is a positive probability of being both treated and untreated for each propensity score $P\left(X_{i}\right)$. Accordingly, the ATT can then be expressed by:

$\left.\mathscr{T}_{\text {ATT }}^{\text {matching }}=E\left(\mathrm{Y}^{1} \mid P\left(X_{i}\right), T=1\right)-E\left(\mathrm{Y}^{0} \mid P\left(X_{i}\right), T=0\right) \mid T=1\right)$

\section{Results}

Table 2 presents the probit estimation results of utilizing the three different forms of E-commerce in SMEs based on different industry characteristics represented by the information intensity of value chain or product. In support of hypothesis 1 , the results show that the probit estimation coefficient is statistically significant and great in magnitude for those SMEs that have their own website, a third-party website or a social media profile in both value chain information intensive and product information intensive industries, and not in a primary industry that is neither information nor product intensive (see Panel A). Furthermore, they are positively signed, which suggests that the utilizing of E-commerce has a positive effect on revenue growth for both value chain information intensive and product information intensive SMEs.

In panel B of Table 2, we also report the marginal effects for probit regression estimators (Greene, 2003). The results are all statistically significant for SMEs that belong to the value chain information intensive industry or the product information intensive industry. As to practical significance, the results indicate that a small firm that has its own website is $13 \%$ and $16 \%$ more likely to experience revenue growth during the past 12 months when compared with its counterpart that does not have its own website. This result holds whether the small firm is in an industry with high information intensity of value chain and product, respectively. The probability that a small organization with a third-party website reports performance growth is $4 \%$ and $5 \%$ higher than those that do not employ such a form of E-commerce in value chain information intensive industry and product information intensive industry, respectively. The marginal effects suggest that small firms which belong to the value chain information intensive industry with a social media profile are $8 \%$ more likely to appear in the higher response category of revenue growth (i.e. 'increased' response category) than those that do not adopt such E-commerce technology. The similar results apply to small enterprises classified as the product information intensive industry.

Next, we examine the simultaneous effects of all three forms of technologies on SME firm performance based on industry characteristics, the results are illustrated in Table 3. Specifically, the probit coefficient and marginal effect results are presented in panels A and B, respectively. Our results reveal that there is a positive but statistically insignificant relationship between having a third-party website and revenue growth of SMEs in the value chain information intensive industry. Whereas, with regards to having its own website and a social media profile, the relationship is statistically significant and positive. On the other hand, the probit regression coefficients for all three forms of web-based E-commerce are statistically significant and positive in SMEs that compete in the product information intensive industry,

Table 2

Probit regression results for the effect of E-commerce on SMEs revenue growth.

\begin{tabular}{|c|c|c|c|c|c|c|}
\hline \multirow{3}{*}{$\begin{array}{l}\text { E-commerce technologies: The } \\
\text { SME has }\end{array}$} & \multicolumn{3}{|c|}{ Panel A: coefficients } & \multicolumn{3}{|c|}{ Panel B: marginal effects } \\
\hline & \multicolumn{3}{|c|}{ Industry characteristics } & \multicolumn{3}{|c|}{ Industry characteristics } \\
\hline & $\begin{array}{l}\text { Primary } \\
\text { industry }\end{array}$ & $\begin{array}{l}\text { Value chain information } \\
\text { intensive }\end{array}$ & $\begin{array}{l}\text { Product information } \\
\text { intensive }\end{array}$ & $\begin{array}{l}\text { Primary } \\
\text { industry }\end{array}$ & $\begin{array}{l}\text { Value chain information } \\
\text { intensive }\end{array}$ & $\begin{array}{l}\text { Product information } \\
\text { intensive }\end{array}$ \\
\hline \multirow[t]{2}{*}{ Its own website } & 0.25 & $0.35^{* *}$ & $0.44^{* *}$ & 0.07 & $0.13^{* * *}$ & $0.16^{* * *}$ \\
\hline & 0.22 & 0.06 & 0.09 & 0.07 & 0.02 & 0.03 \\
\hline Controls & Yes & Yes & Yes & Yes & Yes & Yes \\
\hline Log likelihood & -128.3 & -2275.52 & -1842.31 & -128.3 & -2275.52 & -1842.31 \\
\hline Chi2 (degree of freedom) & $22.14(15)$ & $196.06(16)$ & $174.88(16)$ & $22.14(15)$ & $196.06(16)$ & $174.88(16)$ \\
\hline Obs & 244 & 3455 & 2787 & 244 & 3455 & 2787 \\
\hline \multirow[t]{2}{*}{ A third party website } & 0.08 & $0.11^{* *}$ & $0.13^{* *}$ & 0.02 & $0.04^{* * *}$ & $0.05^{* * *}$ \\
\hline & 0.28 & 0.05 & 0.06 & 0.08 & 0.02 & 0.02 \\
\hline Controls & Yes & Yes & Yes & Yes & Yes & Yes \\
\hline Log likelihood & -128.9 & -2288.54 & -1852.18 & -128.9 & -2288.54 & -1852.18 \\
\hline Chi2 (degree of freedom) & $20.94(15)$ & $170.03(16)$ & $155.14(16)$ & $20.94(15)$ & $170.03(16)$ & $155.14(16)$ \\
\hline Obs & 244 & 3455 & 2787 & 244 & 3455 & 2787 \\
\hline \multirow[t]{2}{*}{ A social media profile } & 0.20 & $0.21^{* *}$ & $0.22^{* * * *}$ & 0.06 & $0.08^{* * *}$ & $0.08^{* * * * *}$ \\
\hline & 0.21 & 0.05 & 0.05 & 0.07 & 0.02 & 0.02 \\
\hline Controls & Yes & Yes & Yes & Yes & Yes & Yes \\
\hline Log likelihood & -128.5 & -2280.35 & -1845.61 & -128.5 & -2280.35 & -1845.61 \\
\hline Chi2 (degree of freedom) & $21.71(15)$ & $186.41(16)$ & $168.28(16)$ & $21.71(15)$ & $186.41(16)$ & $168.28(16)$ \\
\hline Obs & 244 & 3455 & 2787 & 244 & 3455 & 2787 \\
\hline
\end{tabular}

Notes: Primary industry is neither value chain information intensive nor product information intensive.

The values (in italics) below coefficients and marginal effects are standard errors.

**** $p<0.01$.

${ }^{* *} p<0.05$. 
Table 3

Probit regression results for the effect of E-commerce on SMEs revenue growth.

\begin{tabular}{|c|c|c|c|c|c|c|}
\hline \multirow{3}{*}{$\begin{array}{l}\text { E-commerce technologies: the } \\
\text { business has }\end{array}$} & \multicolumn{3}{|c|}{ Panel A: coefficients } & \multicolumn{3}{|c|}{ Panel B: marginal effects } \\
\hline & \multicolumn{3}{|c|}{ Industry characteristics } & \multicolumn{3}{|c|}{ Industry characteristics } \\
\hline & $\begin{array}{l}\text { Primary } \\
\text { industry }\end{array}$ & $\begin{array}{l}\text { Value chain information } \\
\text { intensive }\end{array}$ & $\begin{array}{l}\text { Product information } \\
\text { intensive }\end{array}$ & $\begin{array}{l}\text { Primary } \\
\text { industry }\end{array}$ & $\begin{array}{l}\text { Value chain information } \\
\text { intensive }\end{array}$ & $\begin{array}{l}\text { Product information } \\
\text { intensive }\end{array}$ \\
\hline \multirow[t]{2}{*}{ Its own website } & 0.21 & $0.29^{* * * *}$ & $0.37^{* * * *}$ & 0.06 & $0.11^{* * *}$ & $0.14^{* * * *}$ \\
\hline & 0.23 & 0.07 & 0.10 & 0.07 & 0.02 & 0.03 \\
\hline \multirow[t]{2}{*}{ A third party website } & 0.02 & 0.06 & $0.11^{*}$ & 0.01 & 0.02 & $0.04 *$ \\
\hline & 0.28 & 0.06 & 0.06 & 0.08 & 0.02 & 0.02 \\
\hline \multirow[t]{2}{*}{ A social media profile } & 0.14 & $0.14^{* *}$ & $0.16^{* *}$ & 0.04 & $0.05^{* *}$ & $0.06^{* * *}$ \\
\hline & 0.22 & 0.05 & 0.06 & 0.07 & 0.02 & 0.02 \\
\hline Controls & Yes & Yes & Yes & Yes & Yes & Yes \\
\hline Log likelihood & -128.09 & -2269.83 & -1836.47 & -128.09 & -2269.83 & -1836.47 \\
\hline Chi2 (degree of freedom) & $22.54(17)$ & $207.44(18)$ & 186.56 & 22.54 (17) & 207.44 (18) & 186.56 \\
\hline Obs & 244 & 3455 & 2787 & 244 & 3455 & 2787 \\
\hline
\end{tabular}

Notes: Primary industry is neither value chain information intensive industry nor product information intensive industry.

The values (in italics) below coefficients and marginal effects are standard errors.

**** $p<0.01$.

** $p<0.05$.

${ }^{*} p<0.10$.

suggesting that the launch and maintenance of a company's own website, the use of a third-party website, and a social media profile, all have a simultaneous positive effect on sales growth. Panel B presents the marginal effects results for probit estimators. Specifically, it is $11 \%$ and $5 \%$ more likely for a small business with its own website and a social media profile in the value chain information intensive industry to respond to the 'increased' response category than its counterpart without using similar web-based E-commerce technologies respectively. For a product information intensive small firm that adopts its own company website, a third-party website, and a social media profile, the probability of reporting an improvement in revenue is $14 \%, 4 \%$ and $6 \%$, respectively. Taking into considerations all the above-mentioned results, we conclude that hypothesis 1 is validated.

Hypotheses 2 to 4 compare the magnitude of the likelihood effect of the different development stages of E-commerce on revenue growth in SMEs that belong to the value chain information intensive and product information intensive industries. The estimation results are shown in Table 4. Panel A presents the coefficient results that compare the impact of presence stage and portal stage of having its own business website or a third-party website on sales growth in SMEs feature with high information intensity of value chain or product. The coefficients are not statistically significant in either case, which suggests that the likelihood of sales growth does not vary significantly between presence and portal stages of adopting these two E-commerce technologies (i.e. company with its own website, and a third-party website), irrespective of the types of information intensity of the industry. One possible explanation is that as the information flows increase from the presence to the portal stages, the SMEs are not vertically integrated enough, and this affects sales growth [see Information Processing Model, (Galbraith, 1976)]. Nevertheless, hypotheses $2 \mathrm{a}$ and $2 \mathrm{~b}$ are not supported by the data. Similar results are obtained with regards to whether the likelihood of performance growth is significantly different between the presence and the transaction stages of E-commerce (see Panel B), and between portals and transaction integration stages of E-commerce (see Panel C). Thus, hypotheses $3 \mathrm{a}, 3 \mathrm{~b}, 4 \mathrm{a}$ and $4 \mathrm{~b}$ are not supported. Combining the results related to the four hypotheses, the data supports the idea that SMEs which have their own business website, a third-party website, and/or a social media profile, are more likely to achieve revenue growth rate regardless of which specific form of web-based Ecommerce is used by customers as well as the value chain information intensity or product information intensity of the industry.

To check the robustness of the results, we conducted a kernel matching approach. Specifically, the difference in the probability of reporting increased revenue between treatment groups was estimated by directly estimating the difference in proportions between treated (i.e. utilize any form of E-commerce) and untreated (i.e. not use any form of E-commerce) SMEs in the propensity score matched sample. Table 5 reports the matching results for growth in revenue for the past 12 months for both value chain information intensive and product information intensive small businesses. Our findings imply that the matching procedure is successful. Specifically, the effects are also found to be similar in magnitude to the ones reported earlier. For an SME competing in a high value chain information intensive or product information intensive industry that has a business website, a third-party website, and/or a social media profile, it is more likely to experience an increase in business revenue than those without the respective form of E-commerce, which lends further support to H1.

\section{Discussion}

E-commerce has brought about some major important attributes (such as economics of exchanging information, increased connectivity and interactivity between people, and network economies of scale) that not only facilitate firms to build up a cost-effective marketing and retailing channel in the digital economy, but also enables them to reach an extended customer base, in terms of minimising transport obstacles and eliminating physical limitation of time and space (Lee, 2001; Santarelli and D'Altri, 2003). The entrepreneurial small and medium business sector has been considered as the fastest changing sector of $\mathrm{E}$ commerce. Drawing upon transactional costs economics perspective, we postulated that small firms which engaged in web-based internet commerce should be able to achieve a significantly higher level of penetration and better sales performance, in terms of disintermediation and dealing directly with customers in the online market. Nevertheless, the positive impact of the E-commerce adoption on performance was expected to be conditioned upon information characteristics of the business process and product of information. In addition, we argue that the extent to which the commercial websites and social media profiles influence the performance of small business depends on the level of interactivity and design sophistication (Auger, 2005).

As to implications for theory, the results of this study indicate that all three types of E-commerce increase the likelihood of increased revenue for SMEs characterised with either high intensity of value chain information or high intensity of product information, but there is not a distinguishable difference in likelihood across the different stages of $\mathrm{E}$ commerce development as suggested by Rao et al. (Rao et al., 2003). The 
Table 4

Probit regression for the effect of different stage of E-commerce on firm performance in different industries.

\begin{tabular}{|c|c|c|}
\hline \multirow[t]{2}{*}{ Hypotheses } & \multicolumn{2}{|l|}{ Industry characteristics } \\
\hline & $\begin{array}{l}\text { Value chain information } \\
\text { intensive }\end{array}$ & $\begin{array}{l}\text { Product information } \\
\text { intensive }\end{array}$ \\
\hline \multicolumn{3}{|c|}{ Panel A: H2a)-b) Presence stage vs portal stage } \\
\hline \multicolumn{3}{|c|}{$\begin{array}{l}\text { The business has its own } \\
\text { website }\end{array}$} \\
\hline \multirow[t]{2}{*}{ Portal stage } & 0.17 & -0.04 \\
\hline & 0.52 & 0.19 \\
\hline Controls & Yes & Yes \\
\hline Log likelihood & -69.41 & -1459.80 \\
\hline Chi2 (degrees of freedom) & $13.12(15)$ & $72.76(16)$ \\
\hline Obs & 119 & 2164 \\
\hline \multicolumn{3}{|l|}{$\begin{array}{l}\text { The business has a third } \\
\text { party }\end{array}$} \\
\hline \multirow[t]{2}{*}{ Portal stage } & -0.16 & -0.24 \\
\hline & 0.36 & 0.51 \\
\hline Controls & Yes & Yes \\
\hline Log likelihood & -225.17 & -243.64 \\
\hline Chi2 (degrees of freedom) & $31.79(15)$ & $44.21(16)$ \\
\hline Obs & 348 & 384 \\
\hline \multicolumn{3}{|c|}{ Panel B: H3a)-b) Presence stage vs transaction integration stage } \\
\hline \multicolumn{3}{|c|}{$\begin{array}{l}\text { The business has its own } \\
\text { website }\end{array}$} \\
\hline Transaction integration & -0.06 & 0.25 \\
\hline stage & 0.19 & 0.20 \\
\hline Controls & Yes & Yes \\
\hline Log likelihood & -516.93 & -280.62 \\
\hline Chi2 (degrees of freedom) & $53.45(16)$ & $48.72(16)$ \\
\hline Obs & 785 & 440 \\
\hline \multicolumn{3}{|l|}{$\begin{array}{l}\text { The business has a third } \\
\text { party website }\end{array}$} \\
\hline Transaction integration & -0.30 & 0.54 \\
\hline stage & 0.36 & 0.56 \\
\hline Controls & Yes & Yes \\
\hline Log likelihood & -236.72 & -65.37 \\
\hline Chi2 (degrees of freedom) & $33.54(15)$ & $21.17(14)$ \\
\hline Obs & 366 & 110 \\
\hline \multicolumn{3}{|l|}{$\begin{array}{l}\text { The business has a social } \\
\text { media }\end{array}$} \\
\hline Transaction integration & -0.10 & -0.04 \\
\hline stage & 0.07 & 0.08 \\
\hline Controls & Yes & Yes \\
\hline Log likelihood & -1385.25 & -1249.76 \\
\hline Chi2 (degrees of freedom) & $107.57(16)$ & $102.80(16)$ \\
\hline Obs & 2077 & 1879 \\
\hline \multicolumn{3}{|c|}{ Panel C: H4a)-b) Portals stage vs transaction integration stage } \\
\hline \multicolumn{3}{|c|}{$\begin{array}{l}\text { The business has its own } \\
\text { website }\end{array}$} \\
\hline Transaction integration & 0.02 & 0.02 \\
\hline stage & 0.05 & 0.07 \\
\hline Controls & Yes & Yes \\
\hline Log likelihood & -1922.20 & -1669.99 \\
\hline Chi2 (degrees of freedom) & $105.69(16)$ & $120.20(16)$ \\
\hline Obs & 2855 & 2496 \\
\hline \multicolumn{3}{|l|}{$\begin{array}{l}\text { The business has a third } \\
\text { party website }\end{array}$} \\
\hline Transaction integration & -0.10 & 0.10 \\
\hline stage & 0.10 & 0.15 \\
\hline Controls & Yes & Yes \\
\hline Log likelihood & -448.41 & -311.02 \\
\hline Chi2 (degrees of freedom) & $50.26(15)$ & $45.15(16)$ \\
\hline Obs & 684 & 482 \\
\hline
\end{tabular}

Notes: The values (in italics) below coefficients and marginal effects are standard errors.

former set of findings reminds that not all SMEs can benefit to the same degree from the use of E-commerce technologies, and fundamental differences exist in the nature of products/services and value chain activities provided. Our evidence also collaborates with the prior empirical research that information technology investments contribute positively to firm performance where the value chain information or product information intensity of the industry is deemed as high (Hu and Quan, 2003; Lee and Kim, 2006). On the other hand, the results do not support the prediction of the Rao et al. (Rao et al., 2003) development model of E-commerce. In particular we find no variations in the likelihood of different performance levels, regardless of the different levels of interactivity and design sophistication, of E-commerce technology of the SMEs that are involved in E-business. Also, the results are consistent with the logic that is based on transaction cost theory. However, the survey instrument does not provide information needed to determine if the processes in the logic are the actual drivers of the examined relationships. In short, the seen increases could have been driven by factors put forth in other theories of performance so caution should be used. Only experimental design that explicitly controls for the processes in transaction cost theory could validate which theoretical model is really driving the discovered increases in sales revenue. Additional cautions and avenues for future research are specified in the next section.

As to implications for practice, the results suggest that it will be worthwhile for entrepreneurial SMEs to utilize some form of E-commerce (e.g. its own business website, a third-party website, and/or a social media platform), in terms of achieving sales growth. This is particularly so if the investment in E-commerce technology is in the interest of advancing a small firm's operational efficiency (e.g. cost-saving on marketing and advertising) for the value chain information intensive industry, or if the product and/or service offered by a small organization can be easily digitised and delivered online, or intensive information is required by buyers to use them. The data does not support a difference in likelihood of obtaining an improved revenue among the different types of E-commerce technology options. However, that does not mean that the revenue amount, itself, might differ on the different E-commerce platforms. More information on this idea is presented in the Limitations and future research section. We encourage entrepreneurs to consider including E-commerce technologies in their SME business models.

\subsection{Limitations and future research}

The results of this study are important and help inform the research community and industry by expanding the knowledge base on the associations between E-commerce stages of adoption and financial performance of entrepreneurial SMEs with different industry characteristics. Although this research provides new insights, it has limitations and raises a number of new research questions. In this section, we describe some opportunities for future research arising from limitations given choices that had to be made in the research focus and study design.

A limitation of this study is the use of sales revenue as an indicator of firm performance. Sales revenue is a component of the profit equation and the goal of all firms is the maximization of profits. In fact, the traditional indicators of firm performance are based upon this goal. While, modern indicators are formulated around the goal of attaining the highest capital value. Therefore, sales revenue as a performance indicator does not fully reflect firm performance. For instance, both sales revenue and production costs may increase, thus, reflecting profit gains that are not as large as increases in sales revenue. In other words, production costs which include transaction and marketing costs that are reduced by E-commerce are not captured by growth in sales revenue.

Another limitation is related to the scaling of the dependent variable in the survey conducted by the Department for Business, Innovation \& Skills (BIS) of the United Kingdom government. The survey asked SME leaders to indicate if sales revenue was less, the same, or more than in the past. Given this ordinal categorization, while we can look at whether there is an increase in sales revenue, we cannot examine the amount of the increase. Thus, we caution readers from misinterpreting the findings of the present study. It is the case that there is not a statistical difference looking at comparisons of the SMEs in the three different stages of E-commerce adoption. That is, all three activities result in an improvement in sales revenue for SMEs vs other SMEs 
Table 5

Propensity score matching results.

\begin{tabular}{|c|c|c|c|c|c|c|}
\hline Outcome variable & Obs & Treated & Controlled & Difference & S.E. & t-stat \\
\hline \multicolumn{7}{|l|}{ Value chain information intensive industries } \\
\hline ATT of that the SME has its own website ${ }^{a}$ & 3630 & 0.47 & 0.34 & $0.13^{* * * *}$ & 0.03 & 4.89 \\
\hline ATT Of that the SME has a third party website ${ }^{a}$ & 3630 & 0.47 & 0.43 & $0.04^{* * *}$ & 0.02 & 1.99 \\
\hline ATT of that the SME has a social media profile ${ }^{b}$ & 3630 & 0.48 & 0.39 & 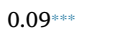 & 0.02 & 5.28 \\
\hline \multicolumn{7}{|l|}{ Product information intensive industries } \\
\hline ATT of that the SME has its own website ${ }^{a}$ & 2962 & 0.49 & 0.3 & 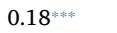 & 0.03 & 5.33 \\
\hline ATT Of that the SME has a third party website ${ }^{a}$ & 2962 & 0.52 & 0.47 & $0.05^{* *}$ & 0.02 & 2.08 \\
\hline ATT of that the SME has a social media profile ${ }^{c}$ & 2962 & 0.51 & 0.43 & $0.08^{* * * *}$ & 0.02 & 3.99 \\
\hline
\end{tabular}

a The observable covariates in the first step (to meet the condition that balance is satisfied) include business capability for people management and accessing external finance, family ownership, firm size, firm age, types of industry, geographical location, legal status, number of sites and owner/partner involvement.

$\mathrm{b}$ The observable covariates in the first step include business capability for people management and accessing external finance, family ownership, firm age, geographical location, legal status, number of sites and owner/partner involvement.

${ }^{\mathrm{c}}$ The observable covariates in the first step include business capability for people management and accessing external finance, family ownership, firm size, firm age, geographical location, legal status, number of sites and owner/partner involvement.

${ }^{* * * *} p<0.01$.

*** $p<0.05$.

that do not engage in any of them, but the likelihood of improvement between the three types of adoption is not 'precise.' What this means is that it could theoretically be the case that while the likelihood of adoption rate (yes/no) of the different groups is not statistically significant, the SMEs that have adopted more complex E-commerce stages might realize a larger increase in revenue than the increase realized by SMEs that have adopted a less complex E-commerce stage. In short, two groups may be nearly equally 'likely' to benefit, but the level of benefit might be very different. Future research is needed that has more precise measurement of the amount of increase in revenue so that we can learn if there is a difference between the groups. Indeed, there might even be differences among different third-party providers such as Amazon, Etsy, eBay, etc., given their different business models [see (Amit and Zott, 2015; Rindova et al., 2012)] which the current database doesn't permit modelling. We hope that future surveys by the government on these important topics will find ways to be more precise in measurement scales on this topic. Understanding the difficulty in getting SMEs to share more precise information, as such precision would permit comparison of costs and revenues associated with the strategic decisions. At a minimum, questions should also be asked if the benefits outweighed the costs involved in implementing each decision.

Future research could also examine other aspects of performance growth. Sales (revenue) is only one of the indicators for growth. Another indicator that impacts growth is brand health, especially in the long run. Brand health not only promotes sales revenue (Ahmad et al., 2006; Heaton, 2015; Pachitanu, 2016), but also consumer loyalty (Berger et al., 2007), which can lead to positive word-of-mouth referrals via the online reviews in the third-party websites (Campanell, 2006; Gamboa and Gonçalves, 2014). Ahmad et al. (Ahmad et al., 2006) imply that it is really about the image as the identity of the business that is ingrained into the consumer, thus, the firm has a forward looking competitive position. Put differently, a healthy brand can create a sustainable and vibrant online community, which augers well for sustainable short and long-term growth (Steimle, 2014). It must be noted that word-of mouth referrals via online reviews are dynamic and interactive in nature. Also, each subsequently later stage of the model by Rao et al. (Rao et al., 2003) is more dynamic and interactive; therefore, one should expect that each stage would have differing impacts on word-of-mouth referrals and brand loyalties. Hence, on growth and/or performance of the SMEs, we did not have such a proxy due to the limitations of the database, and perhaps this is why hypotheses 2,3 and 4 were not validated in this study.

Another question is whether the owners of the SMEs investigated in the study own more than one SME and attempt to gain synergies from them. For example, to what extent might an entrepreneur focus strategically on development for one SME that is linked to a portal on a separate SME that he or she owns, etc.? Baert et al. (Baert et al., 2016) put forth the idea of resource orchestration: the processes through which entrepreneurs structure and rearrange their resources and capabilities across multiple SMEs as they grow a portfolio of SMEs to engage in exploration and exploitation of market opportunities. We believe there would be great value in examining the new concept of resource orchestration put forth by Baert et al. (Baert et al., 2016) as applied to the strategic usage of the different stages of E-commerce technology that is analysed in this present study. It could take the form of asking entrepreneurs to evaluate each SME they own/direct on the relevant metrics and then looking for potential benefits.

Lastly, the survey did not include coverage of different factors that affect the adoption of E-commerce. Sila (Sila, 2013) suggests that there are at least nine adoption factors: pressures from trading partners, pressures from competitors, costs, top management support, trust, network reliability, data security, scalability, and complexity. Feindt et al. (Feindt et al., 2002) suggest others. It will be insightful for both academics and practitioners to understand how the different factors interact with generating additional revenue at the different E-commerce development stages.

\section{Conclusion}

The results of a large size sample of 15,500 entrepreneurs and SME's indicate that all three types of E-commerce development-own business website, third-party website, a social media—raise the likelihood of increased revenue for an SME in the value chain information intensive industry or product information intensive industry, but not for primary industry that is characterised by low information intensity in both value chain information and product information. Thus, the level of industry related value chain information intensity or product information intensity should be accounted for in forecasting models. Furthermore, there is not a distinguishable variation in likelihood across the three stages measured by the levels of interactivity and design sophistication of commercial websites or social media profiles of the SMEs that are already involved in electronic business and several other control variables. It is very important that further research on additional data be performed to examine the magnitude of the potential increase across different E-commerce stages for entrepreneurial SMEs.

\section{Conflict of interest statement}

This research received no grant from any funding agency. It has not been published elsewhere. Finally, the authors declare that they have no conflict of interest. 


\section{References}

Ahmad, N.S., Musab, R., Mior Harunb, M.H., 2006. The impact of social media content marketing (SMCM) towards brand health. Procedia Economics and Finance 37, 331-336.

Akerlof, G., 1970. The market for "lemons": quality and the market mechanism. Q. J. Econ. 84, 488-500.

Amit, R., Zott, C., 2015. Crafting business architecture: the antecedents of business model design. Strateg. Entrep. J. 9 (4), 331-350.

Auger, P., 2005. The impact of interactivity and design sophistication on the performance of commercial websites for small businesses. J. Small Bus. Manag. 43 (2), 119-137.

Auger, P., Gallaugher, J.M., 1997. Factors affecting the adoption of an Internet-based sales presence for small businesses. Inf. Soc. 13 (1), 55-74.

Baert, C., Meuleman, M., Debruyne, M., Wright, M., 2016. Portfolio entrepreneurship and resource orchestration. Strateg. Entrep. J. http://dx.doi.org/10.1002/sej.1227.

Barth, B., Gulbrandsen, T., Schone, P., 2005. Family ownership and productivity: the role of owner management. J. Corp. Finan. 11, 107-127.

Berger, I.E., Cunningham, P., Drumwright, M.E., 2007. Mainstreaming corporate social responsibility: developing markets for virtue. Calif. Manag. Rev. 49, 132-157.

Blank, D., 2014. What Is Content Marketing? (February 12, 2014). Retrieved on 5 December 2016 from. http://www.cmroi.com/2014/02/12/what-is-contentmarketing/.

Caliendo, M., Kopeing, S., 2008. Some practical guidance for the implementation of propensity score matching. J. Econ. Surv. 22 (1), 31-72.

Campanell, M., 2006. Peer pressure. Entrepreneur 34 (9), 46.

Chen, Q., Zhang, N., 2015. Does e-commerce provide a sustained competitive advantage? An investigation of survival and sustainability in growth-oriented enterprises. Sustainability $7,1141-1428$.

Chevalier, J., Mayzlin, D., 2004. The Effect of Word of Mouth on Sales: Online Book Reviews. Yale SOM Working Paper.

Clarysse, B., Bruneel, J., Wright, M., 2011. Explaining growth paths of young technologybased firms: structuring resource portfolios in different competitive environments. Strateg. Entrep. J. 5 (2), 137-157.

Content Marketing Institute, 2015. What is Content Marketing? Forbes 19 Sep. http://www. forbes.com/sites/joshsteimle/2014/09/19/what-iscontentmarketing/\#56a5d9941d70 (6 Dec 2016).

Cornelissen, J., 2014. Corporate Communication: A Guide to Theory and Practice. Sage Publishing, CA.

Dahnil, M.I., Marzuki, K.M., Langgat, J., Fabeil, N.F., 2014. Factors influencing SMEs adoption of social media marketing. Procedia. Soc. Behav. Sci. 148, 119-126.

Daniel, E., Wilson, H., 2002. Adoption intentions and benefits realised: a study of ecommerce in UK SMEs. Journal of Small Business and Enterprise Development 9 (4), 331-348.

De Vany, A.S., Walls, W.D., 1996. Bose-Einstein dynamics and adaptive contracting in the motion picture industry. Econ. J. 439 (106), 1493-1514.

Dellarocas, C., Zhang, X., Awad, N.F., 2007. Exploring the value of online product reviews in forcasting sales: the case of motion pictures. J. Interact. Mark. 21 (4), 24-45.

Dewett, T., Gareth, R.J., 2001. The role of information technology in the organization: a review, model and assessment. J. Manag. 27, 313-346.

Feindt, S., Jeffcoate, J., Chappell, C., 2002. Identifying success factors for rapid growth in SME e commerce. Small Bus. Econ. 19 (1), 51-62.

Galbraith, J.R., 1976. Organization design: an information processing view. Interfaces 4 (3), 28-36.

Galbraith, J.R., 1995. Designing Organizations: An Executive Briefing on Strategy, Structure and Process. Jossey-Bass, San Francisco.

Gamboa, A.M., Gonçalves, H.M., 2014. Customer loyalty through social networks: lessons from Zaraon Facebook. Business Horizons, Special Issue INBAM 57 (6), 709-717.

Garicano, L., Kaplan, S., 2001. The effects of business-to-business E-commerce on transaction costs. J. Ind. Econ. 4, 463-483.

Gogoi, P., 2007. Retailers take a tip from Myspace. Bus. Week Feb. http://www. businessweek.com/bwdaily/dnflash/content/feb2007/db20070213_626293_page 2 (4 Dec 2016).

Greene, W.H., 2003. Econometric Analysis, 5th ed. Prentice Hall, New Jersey.

Heaton, J., 2015. Brand Health. Tronvig Group. http://www.tronviggroup.com/brandhealth (2 Nov 2016.

Hoffman, D.L., Novak, T.P., 1995. Marketing in hypermedia computer-mediated environments: conceptual foundations. J. Mark. 60, 50-68.

Hu, Q., Quan, J., 2003. Information intensity and impact of IT investments on productivity: an industry level perspective. In: ECIS 2003 Proceedings.

Huang, Z., Benyoucef, M., 2013. From e-commerce to social commerce: a close look at design features. Electron. Commer. Res. Appl. 12 (4), 246-259.

Jiang, B.J., Wang, B., 2008. Impact of consumer reviews and ratings on sales, prices, and profits: theory and evidence. In: Proceedings of ICIS. Paper 141.

Johnstone, D.A., Wade, M., McClean, R., 2007. Does e-business matter to SMEs? A comparison of the financial impacts of internet business solutions on European and North American SMEs. J. Small Bus. Manag. 45 (3), 354-361.

Kampkotter, P., Marggraf, K., 2005. Do employees reciprocate to intra-firm trainings? An analysis of absenteeism and turnover rates. Int. J. Hum. Resour. Manag. 26 (22), 2888-2907.

Karavdic, M., Greogory, G., 2005. Integrating e-commerce into existing export marketing theories: a contingency model. Mark. Theory 5, 75-104.

Ke, W., Wei, K.K., 2007. Factors affecting trading partners' knowledge sharing: using the lens of transaction cost economics and socio-political theories. Electron. Commer. Res. Appl. 6, 297-308.

Keller, K.L., 2009. Building strong brands in a modern marketing communications environment. J. Mark. Commun. 15, 139-155.

Kietzmann, J.H., Hermkens, K., McCarthy, I.P., Silvestre, B.S., 2011. Social media? Get serious! Understanding the functional building blocks of social media. Bus. Horiz. 54 (1), 241-251.

Kim, D., 2003. The internationalization of US internet portals: does it fit the process model of internationalization? Mark. Intell. Plan. 21 (1), 23-36.

Kirchhoff, B.A., 1994. Entrepreneurship and Dynamic Capitalism: The Economics of Business Firm Formation and Growth. Praeger, Westport, CT.

Kirchhoff, B.A., Linton, J.D., Walsh, S.T., 2013. Neo-Marshellian equilibrium versus Schumpeterian creative destruction: its impact on business research and economic policy. J. Small Bus. Manag. 51 (2), 159-166.

Lange-Faria, W., Elliot, S., 2012. Understanding the role of social media in destination marketing. Journal of Tourism 7 (1), 193-211.

Laroche, M., Habibi, M.R., Richard, M.O., Sankaranarayanan, R., 2012. The effects of social media based brand communities on brand community markers, value creation practices, brand trust and brand loyalty. Comput. Hum. Behav. 28 (5), 1755-1767.

Le, T., Koh, A.A., 2002. Managerial perspective on electronic commerce development in Malaysia. Electron. Commer. Res. 2, 7-29.

Lee, C., 2001. An analytical framework for evaluating e-commerce business models and strategies. Internet Research 11 (4), 349-359.

Lee, S., Kim, S., 2006. A lag effect of IT investment on firm performance. Inf. Resour. Manag. J. 19 (1), 43-69.

Lightfoot, W., Harris, J.R., 2003. The effect of the internet in industrial channels: an industry example. Ind. Manag. Data Syst. 103 (2), 78-84.

Melville, N., Kraemer, K., Gurbaxani, V., 2004. Review: information technology and organizational performance: an integrative model of IT business value. MIS Q. 28 (2), 283-322.

Milgrom, P., Roberts, J., 1992. Economics, Organization and Management. Prentice-Hall, Englewood Cliffs, NJ (1992).

Misner, I.R., 1999. The World's Best Known Marketing Secret: Building Your Business With Word-of-Mouth Marketing, 2nd ed. Bard Press, Austin (1999).

Morris, M., Schindehutte, M., Richardson, J., Allen, J., 2006. Is the business model a useful strategic concept? Conceptual, theoretical, and empirical insights. Journal of Small Business Strategy 17, 27-50.

Nelson, P., 1974. Advertising as information. J. Polit. Econ. 82 (4), 729-754.

O'Connor, G.C., O'Keefe, B., 1997. Viewing the web as marketplace: the case of small companies. Decis. Support. Syst. 21, 171-183.

Olson, P.D., Zuiker, V.S., Danes, S.M., Stafford, K., Heck, R.K.Z., Duncan, K.A., 2003. The impact of the family and the business on family business sustainability. J. Bus. Ventur. 18, 639-666.

Öztamur, D., İbrahim, S.K., 2014. Exploring the role of social media for SMEs: as a new marketing strategy tool for the firm performance perspective. Procedia. Soc. Behav. Sci. $150,511-520$

Pachitanu, A., 2016. Communication in the digital era and online corporate communications strategies-untapped opportunities for businesses in Romania. Eastern European Business and Economics Journal 2 (1), 27-42.

Porter, M.E., Millar, V.E., 1985. How information gives you competitive advantage. Harv. Bus. Rev. 63 (4), 149-160.

Preissl, B., 2003. E-business in Service Industries: Usage Patterns and Service Gap. German Institute for Economic Research, DIW.

Quayle, M., 2002. E-commerce: the challenge for UK SME-s in the twenty-first century. Int. J. Oper. Prod. Manag. 22 (10), 1148-1161.

Ramanathan, R., Ramanathan, U., Hsiao, H., 2012. The impact of e-commerce on Taiwanese SMEs: marketing and operations effects. Int. J. Prod. Econ. 140, 934-943.

Rao, S.S., Metts, G., Mora Monge, C.A., 2003. Electronic commerce development in small and medium sized enterprises: a stage model of its implication. Bus. Process. Manag. J. 9 (1), 11-32.

Rheingold, H., 1993. The Virtual Community. MIT Press, Massachusetts.

Rindova, V.P., Yeow, A., Martins, L.L., Faraj, S., 2012. Partnering portfolios, valuecreation logics, and growth trajectories: a comparison of Yahoo and Google (1995 to 2007). Strateg. Entrep. J. 6 (2), 133-151.

Rotondaro, R.G., 2002. Defining the customer's expectations in e-business. Ind. Manag. Data Syst. 102, 476-482.

Santarelli, E., D'Altri, S., 2003. The diffusion of E-commerce among SMEs: theoretical implications and empirical evidence. Small Bus. Econ. 21 (3), 273-283.

Schwartz, E.I., 1997. Webonomics - Nine Essential Principles for Growing Your Business on the World Wide Web. Broadway Books, New York, NY.

Sciascia, S., Mazzola, P., Astrachan, J.H., Pieper, T.M., 2012. The role of family ownership in international entrepreneurship: exploring nonlinear effects. Small Bus. Econ. 38, 15-31.

Senecal, S., Nantel, J., 2014. The influence of online product recommendations on consumers' online choices. J. Retail. 80, 159-169.

Shin, N., 2001. Strategies for competitive advantage in electronic commerce. Journal of ElectronicCommerce Research 2 (4), 164-171.

Sila, I., 2013. Factors affecting the adoption of B2B e-commerce technologies. Electron. Commer. Res. 13 (2), 199-236.

Sinkovics, R.R., Penz, E., 2006. Empowerment of SME websites development of a web empowerment scale and preliminary evidence. J. Int. Entrep. 3 (4), 303-315.

Steimle, I., 2014. What is Content Marketing? Forbes 19 Sep.hb. http://www.forbes. com/sites/joshsteimle/2014/09/19/what-is-contentmarketing/\#56a5d9941d70 (24 Nov 2016).

Storey, D., 1994. Understanding the Small Business Sector. Routledge, London and New York.

Thompson, N., 2003. More companies pay heed to their 'Word of Mouse' reputation. The New York Times June 23. http://www.nytimes.com/2003/06/23/business/ technology-more-companies-pay-heed-to-their-word-of-mouse-reputation.html (6 
Dec 2016).

Timmers, P., 1999. Electronic Commerce, Strategies and Models for B2B Trading. Wiley, New York, NY, New York NY.

Timmers, P., 2001. Global and local in electronic commerce. EC-web 2000: Electronic Commerce and Web. Technology 91-205.

de Valck, K., van Bruggen, G.H., Wierenga, B., 2009. Virtual communities: a marketing perspective. Decis. Support. Syst. 47 (3), 185-203.

Wainwright, C., 2014. Content Marketing Strategy: A Comprehensive Guide for Modern Marketers. July 21. https://blog.hubspot.com/marketing/content-marketingstrategy-guide\#sm.00015fmhkepcjdocscl1asm38dpou (11 Dec 2016).

Wen, H.J., Chen, H.-G., Hwang, H.-G., 2001. E-commerce web site design: strategies and models. Information Manage Comput Security 9 (1), 5-12.

Williamson, O.E., 1991. Comparative economic organization: the analysis of discrete structural alterantives. Adm. Sci. Q. 36 (2), 269-296.

Wood, R., Bandur, A., 1989. Social cognitive theory of organizational management. Acad. Manag. Rev. 14 (3), 361-384.

Young, A., 2014. Brand Media Strategy: Integrated Communications Planning in the Digital Era. Palgrave Macmillan, London, London.

Zhu, K., Kraemer, K.L., 2002. E-commerce metrics for net-enhanced organizations: assessing the value of e-commerce to firm performance in the manufacturing sector. Inf. Syst. Res. 13 (3), 275-295.

George Saridakis is Professor of Small Business and Entrepreneurship at Kingston University Business School and Honorary Professor at the University of the West Indies. $\mathrm{He}$ is also Editor of the International Small Business Journal Special Issue on "Enterprise
Activity, Performance and Policy during Times of Crisis" and co-editor of the book on "How Can HR Drive Growth?"

Yanqing Lai has recently defended her $\mathrm{PhD}$ thesis. Her project was carried out at Kingston University Business School investigating "Employee Relations in SMEs". Yanqing holds a Master's degree (with distinction) from the University of Manchester and a Bachelor's degree from the University of Nottingham. She received the Best Research Student Performance Award in 2015. Currently she is Research Assistant at Edinburgh Napier University.

Anne-Marie Mohammed is currently the Head of Department and Lecturer in the Department of Economics, Faculty of Social Sciences, The University of the West Indies, St. Augustine, Trinidad and Tobago. She attained her B.Sc. (First Class Honours), M.Sc. and Ph.D. degrees in (Economics) from The University of the West Indies, St. Augustine in 1997, 2000 and 2008 respectively. As part of the split-site Ph.D. programme she spent one year at New York University supervised by Professor William J. Baumol.

Jared M. Hansen, Ph.D., is Associate Professor of Marketing in the Belk College of Business at UNC Charlotte. He received his Ph.D. in Marketing from Texas Tech University and his marketing emphasis MBA and engineering Bachelor's degree from Brigham Young University. Drawing on his past and current professional industry experiences, he continues to publish and speak on managerially relevant, fundamental, and cutting-edge issues that further our understanding of individual and firms in the competitive marketplace and society. 